\title{
RECOVERY OF ZnO FROM LEAD-ZINC FLOTATION TAILINGS BY HYDROMETALLURGICAL PROCESSES - XRD, SEM, AND AFM STUDIES
}

\author{
K.T. Perek¹, B. Benli' , C. Arslan², F. Arslan"\# \\ ${ }^{1}$ Istanbul Technical University, Mineral Processing Engineering Department, Istanbul, Turkey \\ ${ }^{2}$ |stanbul Technical University, Metallurgical and Material Engineering Department, Istanbul, Turkey
}

(Received: January 14, 2020; Accepted: March 23, 2020)

\begin{abstract}
The hydrometallurgical route of zinc hydroxide and synthesis of nanocrystalline $\mathrm{ZnO}$ is a particularly attractive method to recover oxidized lead and zinc from lead-zinc flotation tailings. In Turkey, lead-zinc complex/mixed ores along with high iron content are not suitable for conventional mineral processing methods and need hydrometallurgical treatments. Therefore, the control of iron during zinc processes is really important. In this study, hydrometallurgical process route for zinc recovery from $\mathrm{Pb}$-Zn flotation tailings was investigated by considering the effects of $\mathrm{H}_{2} \mathrm{SO}_{4}$ concentration, leaching and roasting temperatures on the zinc dissolution considering the $\mathrm{Eh}-\mathrm{pH}$ variations. The iron and zinc products were also individually examined by X-ray Diffraction (XRD), Scanning Electron Microscopy (SEM) and Atomic Force Microscopy (AFM) images in order to compare before and after leaching, precipitation and roasting steps. $83.1 \% \mathrm{Zn}$ and $91.6 \% \mathrm{Cd}$ leaching efficiencies were obtained from $\mathrm{Pb}$ - $\mathrm{Zn}$ flotation tailing particles with the size range of 50-110 nm from AFM image cross-sections, while lead and iron were not dissolved. Elemental sulfur started to form and produce a layer around the particles or a partially agglomerated particle in the size of $170 \mathrm{~nm}$ during the sulphuric acid leaching. However, majority of the particles was determined to be less than 20 microns, and AFM images showed that the size reduction between the leached and unleached particles was over $50 \%$.

Selective precipitations of iron and zinc in the form of hydroxide were performed in high recovery efficiencies of $90.1 \%$ and $99 \%$, respectively. After the heat treatment, nanocrystalline zincite clusters of $96.6 \%$ purity were produced in the $\mathrm{ZnO}$ mineral form and nearly $13 \mathrm{~nm}$ in size. Zinc can be successfully recovered and a flotation tailings ore can be a good candidate for the production of high technology needs of nanocrystalline ZnO nanoparticles.
\end{abstract}

Key words: Pb-Zn ores; Leaching; Precipitation; Zinc oxide clusters; Zincite structure.

\section{Introduction}

Zinc, especially in the form of zinc oxide $(\mathrm{ZnO})$, is the key element for semiconductor and piezoelectric materials in electronics, optics, and photonics, as well as the raw material for other important industrial applications including white pigment, plastics, ceramics, glass, cement, paints, and fire retardants, etc. [1]. Since zinc oxide shows different purity and particle characteristics depending on the synthesis methods [2, 3], many grades of $\mathrm{ZnO}$ particles [4] could be synthesized to meet the diverse industry requirements such as controlled burning of zinc metal vapor in air (French process), chemical vapor deposition, electrodeposition, pulsed laser deposition, sol-gel synthesis, and spray pyrolysis. Among them, room temperature solution route (hydro-thermal method) is particularly attractive because it is a simple and catalyst-free process.

The hydrometallurgical route of zinc oxide is primarily based on zinc hydroxide or basic zinc carbonate $[5,6]$. The common recovery method of oxidized lead and zinc minerals from lead-zinc ores at present is flotation in practice [7 - 9]. In Turkey, there are lead - zinc complex/mixed ores with high iron content that are not suitable for concentration with conventional mineral processing methods due to their complex mineralogy and need hydrometallurgical treatment [10, 11]. Even the most efficient concentrators generally produce zinc concentrate with significant iron content. Therefore, iron is usually removed from leaching solutions by precipitation methods such as jarosite, goethite, paragoethite, and hematite processes [12 - 16]. However,

\#Corresponding author: arslanf@itu.edu.tr

doi: 10.5937/JMMA2001023P 
some environmental problems become evident during the disposal of jarosite. In order to overcome these problems, it is required to remove iron from aqueous solutions as marketable iron products such as hematite which can be used as a pigment and a raw material in iron-steel industry. Besides, the world's zinc production is mostly obtained by the roast-leach-electrowinning processes. Since zinc electrowinning needs very pure zinc sulphate solution, the purification process is one of the most important downstream unit processes in zinc hydro/electrometallurgy. Zinc can be easily precipitated as hydroxide after iron removal from solution by simply adjusting the $\mathrm{pH}$ values.

The use of industrial residues or $\mathrm{Pb}-\mathrm{Zn}$ ore flotation tailings $[17,18]$ appears attractive in order to improve innovative products through conventional technology and possibly a good candidate to improve resource management, energy efficiency and environmental impacts, i.e. recovery of metallic zinc from galvanizing plant wastes [19], recycling of ZnO flue dust [20], electric arc furnace dust [21], and scrapped lead acid batteries [22]. Recovery and recycling of valuable materials, in our case Zn-hydroxide recovery, from industrial residues also reduce the amount of wastes to be finally disposed and thus reduce the waste disposal problems. These days, environmental and economic considerations coupled with scientific and technological developments have again brought into focus the tailings ponds as potential sources of raw materials.

The aim of this experimental work was to make a consideration to improve the recovery of $\mathrm{ZnO}$ particles from the flotation tailings of the Lead-Zinc-Copper Concentration Plant. In this study, Scanning Electron Microscopy (SEM) and Atomic Force Microscopy (AFM) images of the $\mathrm{Pb}-\mathrm{Zn}$ flotation tailings before and after the leaching and precipitation processes were used to understand how hydrometallurgical route affected the particle characteristics such as the shape and size of iron and zinc particles during $\mathrm{ZnO}$ production from $\mathrm{Pb}-\mathrm{Zn}$ flotation tailings.

\section{Materials and methods}

The dry fine flotation tailings used in this experimental study were obtained from a flotation plant of complex lead-zinc oxide ores (containing $10.17 \% \mathrm{~Pb}, 10.98 \% \mathrm{Zn}$, $57 \mathrm{~g} / \mathrm{t} \mathrm{Ag}$, and $164 \mathrm{~g} / \mathrm{t} \mathrm{Cd}$ ) located near Kayseri-Aladağ region of Turkey. The chemical analysis of the sample was carried out by XRF analyzer (Thermo Scientific NITON XL3t) and the $\mathrm{Zn}, \mathrm{Pb}$, and Fe content of representative flotation tailings sample were found as $7.74 \%, 2.66 \%$, and $21.24 \%$, respectively.

Figure 1 shows the experimental flowsheet for both leaching and precipitation steps. First step was hot acid leaching experiments using sulfuric acid (Merck, 95-98\% purity) to dissolve only $\mathrm{Zn}$ and $\mathrm{Cd}$ since $\mathrm{Pb}$ does not dissolve in $\mathrm{H}_{2} \mathrm{SO}_{4}$ solutions. Acidic leaching experiments were carried out in a $2-L$ beaker and continuously agitated by a mechanical stirrer at specified temperatures. The redox potential (Eh) and $\mathrm{pH}$ were also periodically measured. After filtered and washed with distilled water, the leach residues were separated. Leach liquors were analyzed for $\mathrm{Zn}, \mathrm{Cd}$, and Fe by Atomic Absorption Spectrometer (AAS) of Perkin-Elmer.

In the second step, selective precipitation of iron was carried out at $\mathrm{pH} 4$ by chemical precipitation. Iron hydroxide was separated by filtration and the remaining solution was sent to zinc precipitation.

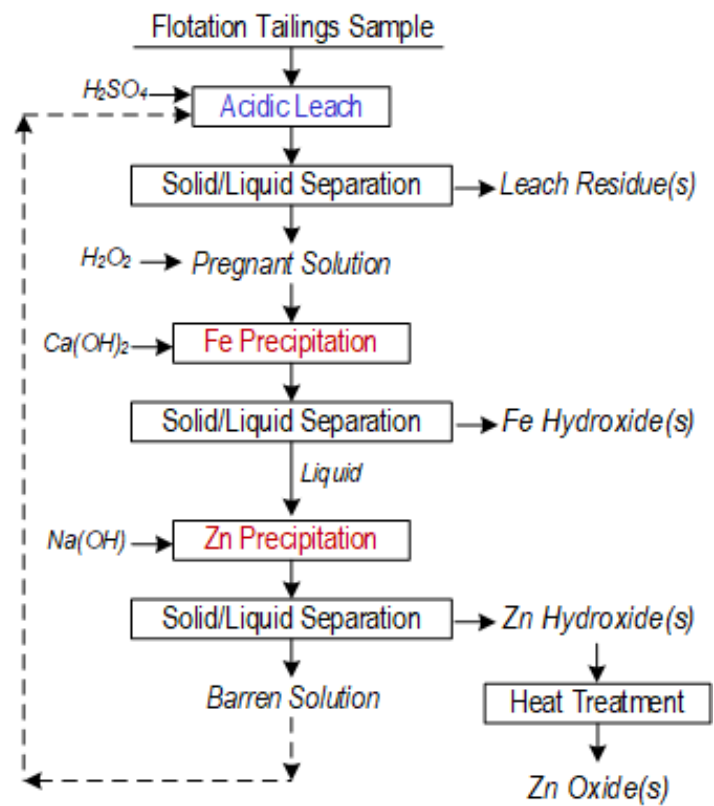

Figure 1 Experimental flowsheet for recovering $\mathrm{ZnO}$ from lead-zinc ore flotation tailings

In the third step, Zn-hydroxide was precipitated at $40^{\circ} \mathrm{C}$ and $\mathrm{pH} 11-12$ using the same set-up of Feprecipitation. After filtration, Zn-hydroxide precipitate was washed with distilled water several times and dried at $105^{\circ} \mathrm{C}$. The dried $\mathrm{Zn}$-hydroxide was then subjected to heat treatment to produce $\mathrm{ZnO}$ at $1100^{\circ} \mathrm{C}$ for $30 \mathrm{~min}$. The phase composition of the prepared zinc oxide was determined by X-Ray Diffraction (XRD) analysis, Scanning 
Electron Microscopy (SEM) and Atomic Force Microscopy (AFM) images as suggested in the literature [23].

Characterization studies conducted by using XRD, SEM and AFM are explained below:

X-Ray Diffraction (XRD) Analysis: The crystal structure of the precipitate was characterized by X-Ray Diffraction (XRD) analysis (BRUKER X-ray Diffractometer model 'Advanced D8') using CuKa $(\lambda=0.15418 \mathrm{~nm})$ at $40 \mathrm{kV}$ and $250 \mathrm{~mA}$. Data was collected at room temperature at $2 \theta=10^{\circ}$ to $90^{\circ}$.

Scanning Electron Microscopy (SEM) Analysis: SEM images were obtained using a Hitachi S-3000H scanning electron microscope (Hitachi, Tokyo, Japan). Images were obtained from the leaching and precipitation media after leach and precipitation process for iron, zinc, and zinc oxide product. The SEM images of the samples were taken under the following conditions: $1024 \times 1024$ pixel; voltage, $15 \mathrm{kV}$; probe size, $20 \mathrm{~nm}$; magnification, $5,000 x$.

Atomic Force Microscopy (AFM) Imaging and Size Measurement Procedure: The depositing procedure on high-quality mica was previously defined for sepiolite fibers [24], montmorillonite, and smectite type clay minerals $[25,26]$. To spread precipitated $\mathrm{Fe}$ and $\mathrm{Zn}$ suspension $\left(0.1 \mathrm{~g}\right.$ in $\left.50 \mathrm{ml} \mathrm{H}_{2} \mathrm{O}\right)$, a dilute suspension of 1 $\mathrm{ml}$ was dropped on the freshly cleaved mica surface followed by drying the sample in a Petri dish at room conditions for 24 hours. Before taking images, samples were cleaned by blowing nitrogen gas through the substrate. The AFM measurements were obtained using Park System XE70 Atomic Force Microscopy (Park System, Park Systems Corp., Suwon, Korea). AFMcontact mode was performed using $910 \mathrm{M}-\mathrm{NSC} 36 / \mathrm{Cr}-$ Au-type cantilevers with $0.5 \mathrm{~Hz}$ scanning speed and acquisition points were $515 \times 512$. The AFM tips were cleaned by a UV ozone cleaner chamber (UV/Ozone ProCleaner, Bioforce Nanosciences Inc., IA, US) under UV radiation for $30 \mathrm{~min}$ prior to use. In order to provide a three-dimensional surface profile and height measurements corresponds to the diameter or size of the particle with a high degree of accuracy and precision, AFM images of the samples such as tailings particles, leaching products, zinc oxide and iron precipitate particles were also processed by XEl software (Park Systems Corp., Suwon, Korea). There are also some characterization studies by AFM on $\mathrm{ZnO}$ particles and coatings [27 - 29].

\section{Results and discussion}

Experimental results were discussed in two main parts namely hydrometallurgical processes (hot acidic leaching, iron precipitation, and zinc hydroxide precipitation) followed by the heat treatment, and studies on SEM and AFM images of all products.

\subsection{Hydrometallurgical Processes with $\mathrm{Pb}-\mathrm{Zn}$ flotation tailings}

\subsubsection{Acidic leaching studies}

In these tests the effect of acid concentration, temperature, and roasting prior to leaching on metal dissolution efficiencies was tested. Eh-pH measurements were also carried out.

\section{Effect of acid concentration:}

The constant experimental conditions were provided as $60^{\circ} \mathrm{C}$ temperature, $1 / 10 \mathrm{~S} / \mathrm{L}$ ratio, $60 \mathrm{~min}$ of leaching time, and $400 \mathrm{rpm}$ stirring speed where acid concentration varied between $0-80 \mathrm{~g} / \mathrm{L}$. Figure 2 shows the effect of acid concentration on the zinc dissolution where Figure 3 indicates the Eh-pH variations during leaching process further indicating the dissolution areas of $\mathrm{Zn}$ (Figure 4) and Fe (Figure 5). Zinc dissolution efficiency increased gradually up to $60 \mathrm{~g} / \mathrm{L}$ acid $\left(\mathrm{H}_{2} \mathrm{SO}_{4}\right)$ concentration and stabilized after that point. The highest Zn leaching efficiency was $90 \%$ at 80 $\mathrm{g} / \mathrm{L}$ acid concentration with an acid consumption of 579 kg/t.

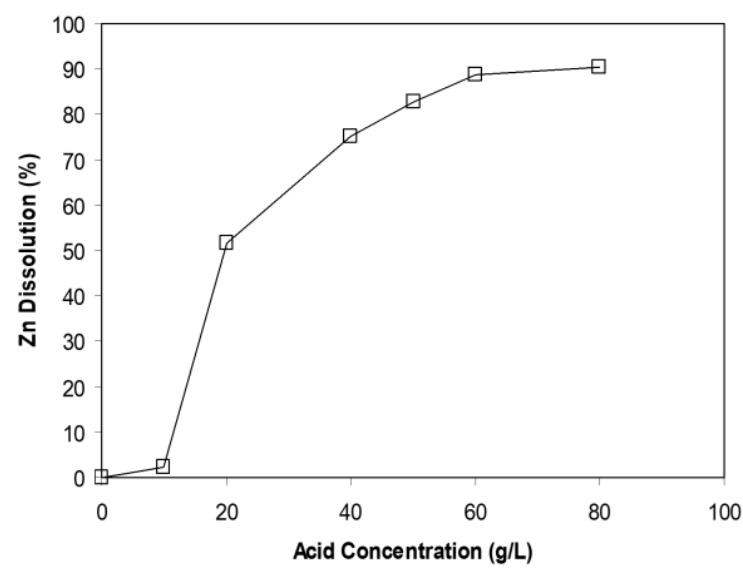

Figure 2 Effect of acid concentration on $\mathrm{Zn}$ dissolution efficiency 


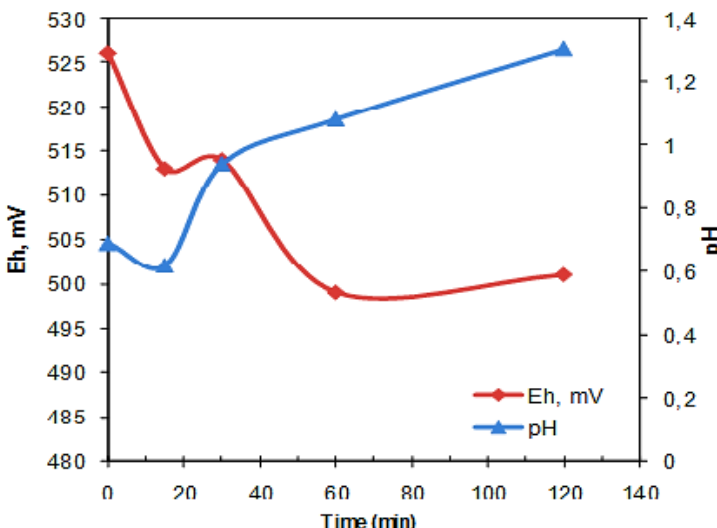

Figure 3 Eh (potential) and $\mathrm{pH}$ variations versus time during zinc leaching process

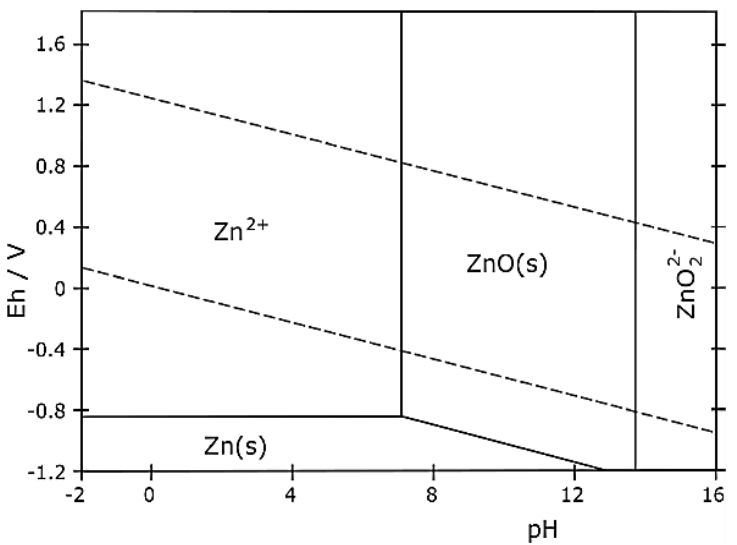

Figure 4 Eh and pH diagram for Zn-water system [30]

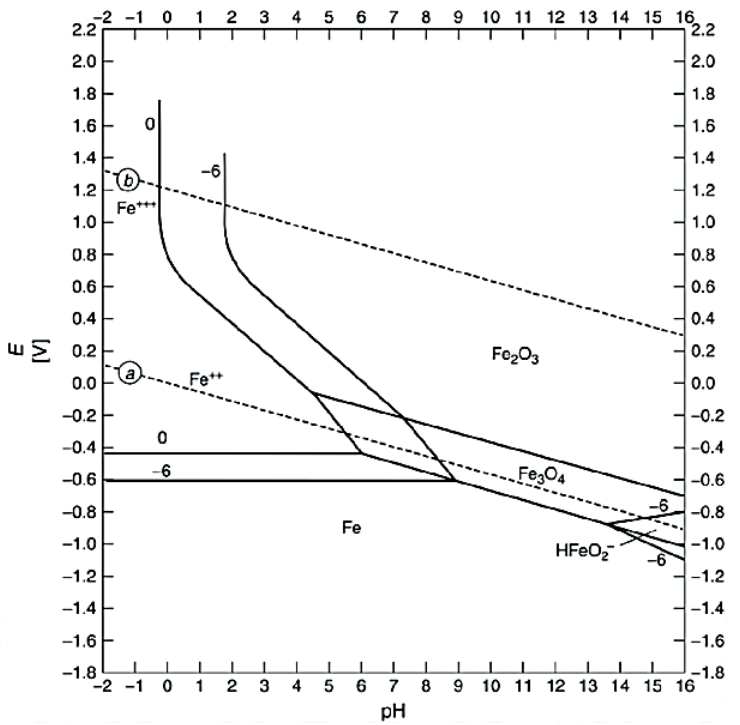

Figure 5 Eh and pH diagram for Fe-water system [30]

\section{Effect of temperature:}

Experiments were run under constant conditions of $60 \mathrm{~g} / \mathrm{L}$ acid concentration, 1/10 S/L ratio, and $400 \mathrm{rpm}$ stirring speed. The effect of temperature (between 20$80^{\circ} \mathrm{C}$ ) on $\mathrm{Zn}$ dissolution relative to leaching time is shown in Figure 6. Increasing temperature increased the curves to the higher values up to $60^{\circ} \mathrm{C}$ temperature and no further increase was observed; therefore, $60^{\circ} \mathrm{C}$ was found as the optimum temperature for effective zinc dissolution and 30 min of leaching time was also sufficient.

The optimum leaching conditions were found as 30 min of leaching time, $60^{\circ} \mathrm{C}$ of leaching temperature and $60 \mathrm{~g} / \mathrm{L}$ of acid concentration. $91.5 \% \mathrm{Zn}, 79.2 \% \mathrm{Cd}$, and $14.3 \% \mathrm{Fe}$ leaching efficiencies were obtained at the optimum conditions while $\mathrm{Pb}$ remained in the leaching residue, and the acid consumption was about $467 \mathrm{~kg} / \mathrm{t}$.

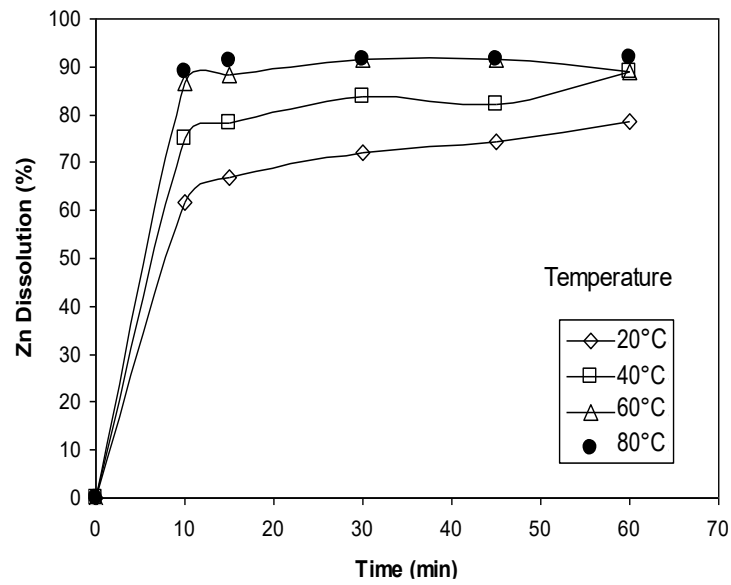

Figure 6 Effect of leaching temperature on $\mathrm{Zn}$ dissolution

\section{Effect of roasting prior to leaching:}

In the roasting-acidic leaching experiments, the effects of roasting temperature, leaching temperature, and acid concentration on the zinc dissolution efficiency of the calcine were investigated [31]. The constant experimental conditions of leaching were $20 \mathrm{~g} / \mathrm{L}$ acid $\left(\mathrm{H}_{2} \mathrm{SO}_{4}\right)$ concentration, 1/5 S/L ratio, 1 hour leaching time, and $400 \mathrm{rpm}$ stirring speed. Figure 7 shows the effect of roasting temperature in relation to leaching temperature and as seen $400^{\circ} \mathrm{C}$ of roasting temperature and $60^{\circ} \mathrm{C}$ leaching temperature were found to be the optimum.

The optimum leaching conditions were $60^{\circ} \mathrm{C}$ leaching temperature, $1 / 5 \mathrm{~S} / \mathrm{L}$ ratio, 1 hour leaching time, and 400 rpm stirring speed. Effect of acid concentration on $\mathrm{Zn}$ 
dissolution from the calcine roasted at $400^{\circ} \mathrm{C}$ is shown in Figure 8. Increasing the acid concentration had an increasing effect up to $50 \mathrm{~g} / \mathrm{L}$ acid concentration and did not change after that point. Therefore, $50 \mathrm{~g} / \mathrm{L}$ acid concentration was found as the optimum value. On the other hand, using the optimum leaching conditions, 83.1\% $\mathrm{Zn}$ and $91.6 \% \mathrm{Cd}$ dissolution efficiencies were obtained while lead and iron were not dissolved and the acid consumption was around $442.9 \mathrm{~kg} / \mathrm{t}$.

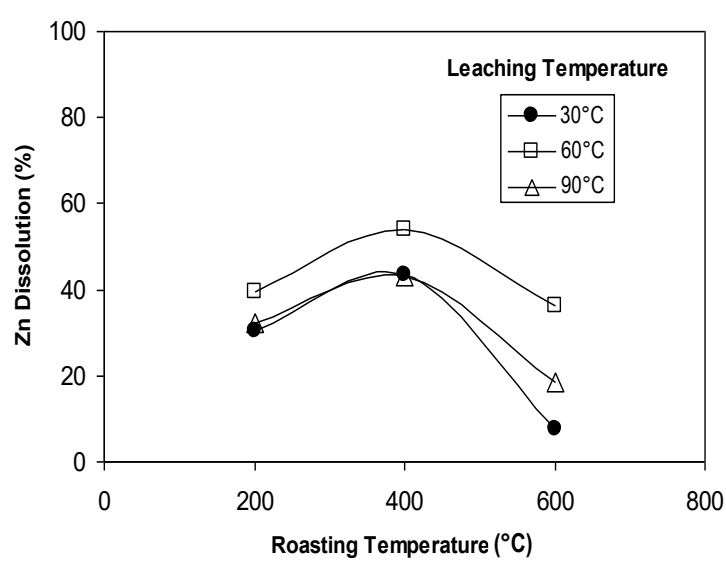

Figure 7 Effect of roasting and leaching temperatures on $\mathrm{Zn}$ dissolution

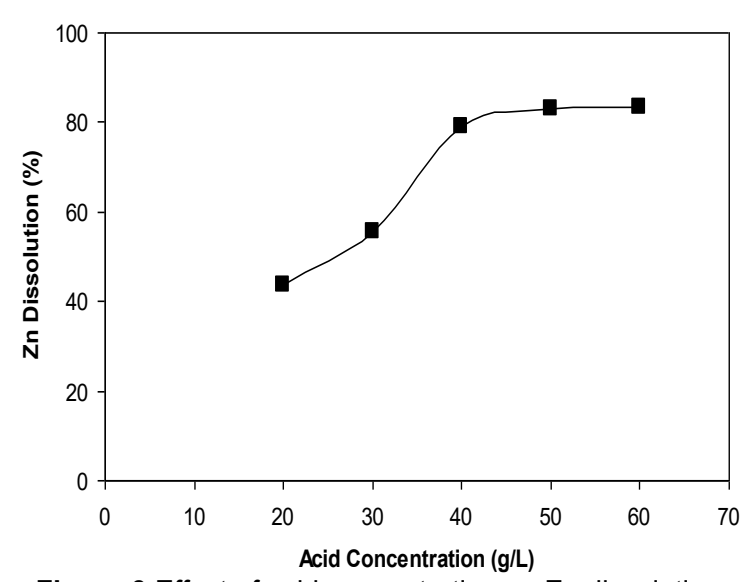

Figure 8 Effect of acid concentration on $\mathrm{Zn}$ dissolution from calcine

The leaching reaction of zinc oxide by sulfuric acid solutions can be expressed as follows:

$$
\mathrm{ZnO}+\mathrm{H}_{2} \mathrm{SO}_{4} \rightarrow \mathrm{ZnSO}_{4}+\mathrm{H}_{2} \mathrm{O}
$$

Similar to this experimental study, Yoshida (2003) analyzed the effects of temperature, agitation speed, initial acid concentration, and particle size on the kinetics of zinc extraction from EAF dusts in a sulfuric acid solution on the basis of above reaction [32]. The activation energy of the zinc oxide leaching with sulfuric acid was found $17.5 \mathrm{~kJ} / \mathrm{mol}$ by the Arrhenius plot showing that the reaction rate of zinc oxide leaching was controlled by mass transfer through the liquid boundary layer. Activation energy was also calculated as $20.7 \mathrm{~kJ} / \mathrm{mol}$ in the temperature range of $313 \mathrm{~K}$ to $353 \mathrm{~K}$, for zinc recovery from metal oxide varistors (MOVs) with sulfuric acid [33].

\subsubsection{Selective Precipitation of Iron and Zinc}

Iron was precipitated from leach solutions at $60^{\circ} \mathrm{C}$ temperature and a $\mathrm{pH}$ range of $4.2-4.3$ by adding $\mathrm{Ca}(\mathrm{OH})_{2}$. Figure 9 gives the Eh-pH variation versus time during the selective iron precipitation experiments. $\mathrm{Fe}$ precipitation efficiency was about $90.1 \%$. However, a small amount of $\mathrm{Zn}$ precipitation was also observed along with $\mathrm{Fe}$. Then, zinc was precipitated in hydroxide form at $40^{\circ} \mathrm{C}$ and $\mathrm{pH}$ of $11-12$ adjusted by the addition of $\mathrm{NaOH}$ according to the following reaction with $99 \%$ efficiency:

$$
\mathrm{ZnSO}_{4}+4 \mathrm{NaOH} \rightarrow \mathrm{Zn}(\mathrm{OH})_{2}+\mathrm{H}_{2} \mathrm{SO}_{4}
$$

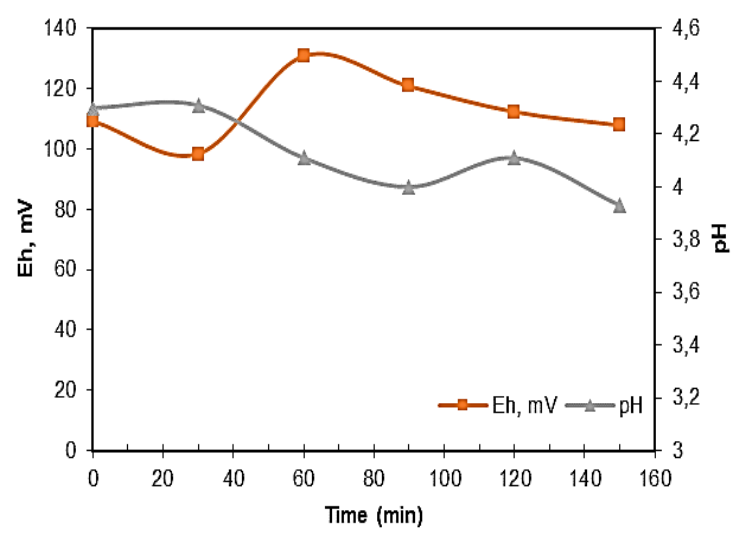

Figure 9 Eh-pH variation versus time during the precipitation of iron

\subsubsection{Nanocrystalline $\mathrm{ZnO}$ powders production}

Zinc hydroxide was subjected to heat treatment to produce $\mathrm{ZnO}$ at $1100^{\circ} \mathrm{C}$ according to the following reaction:

$\mathrm{Zn}(\mathrm{OH})_{2} \rightarrow \mathrm{ZnO}+\mathrm{H}_{2} \mathrm{O}$

X-ray powder diffraction pattern of the $\mathrm{ZnO}$ precipitate can be seen in Figure 10. The XRD pattern of 
$\mathrm{ZnO}$ phase was in agreement with synthetic zincite. The diffraction peaks in the pattern can be indexed to hexagonal zincite structure which is the mineral form of Counts
$\mathrm{ZnO}$ with no impurity of $\mathrm{Zn}$ and $\mathrm{Zn}(\mathrm{OH})_{2}$. The purity of $\mathrm{ZnO}$ product as a result of the experimental procedure (Figure 1) was found at $96.6 \%$.
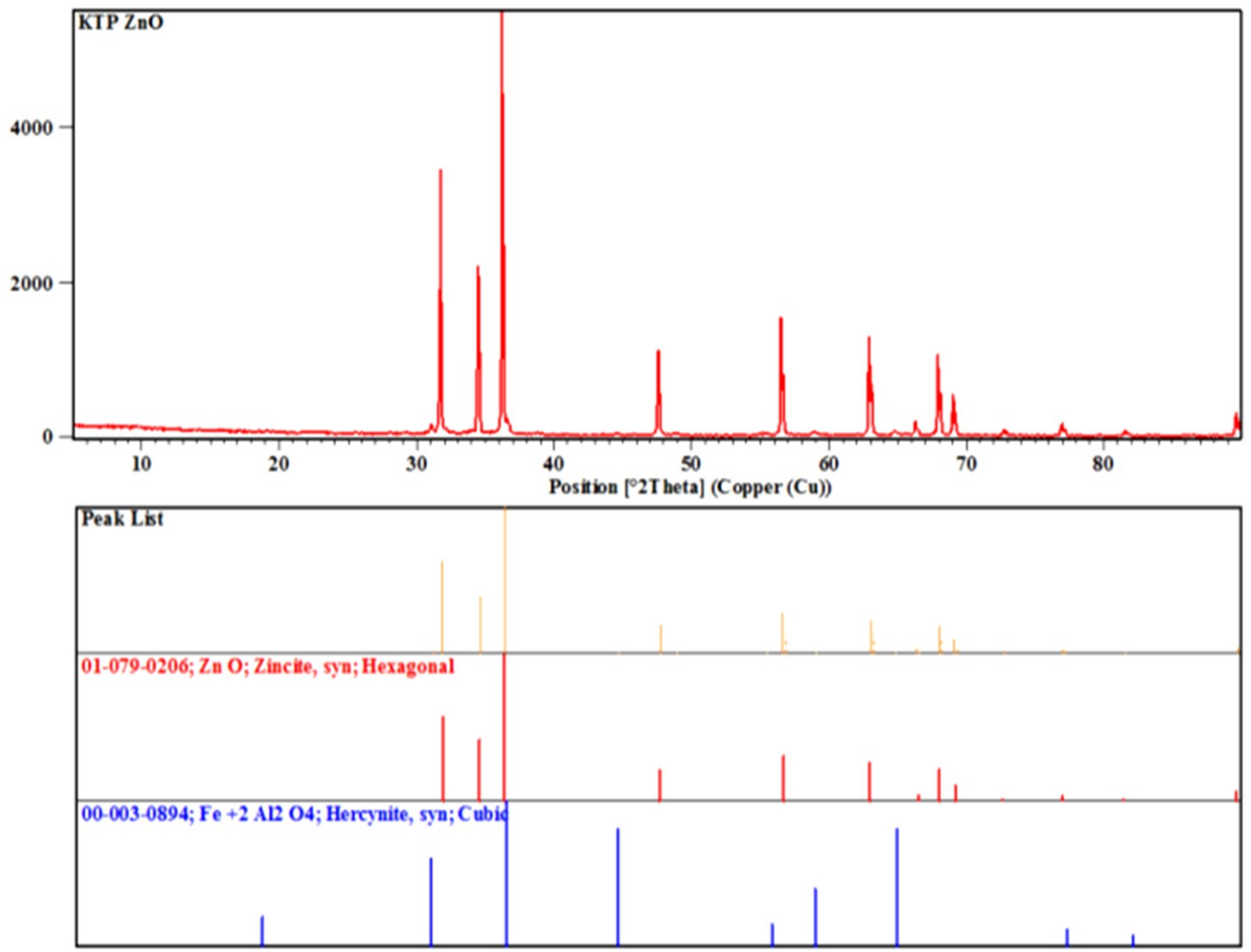

Figure $10 \mathrm{XRD}$ analysis of $\mathrm{ZnO}$

\subsection{SEM and AFM Characterization of} hydrometallurgical route products and zinc oxide

Figure 11 shows Atomic Force Microscopy (AFM) image of $\mathrm{Pb}-\mathrm{Zn}$ flotation tailing particles with a clear surface. The flotation tailing sample included the larger and the smaller dispersed particles after stirring in water for $5 \mathrm{~min}$. The sizes of these particles were measured from their three-dimensional surface profile (Figure 12). Although the lateral dimensions were influenced by the shape of the probe, the height measurements provided very useful information about the height of the tailing particles with a high degree of accuracy and precision. If the particles were assumed to be spherical, the height measurements corresponded to the diameters or sizes of the particles for the larger (red line) and smaller particles (green line) were determined approximately $110 \mathrm{~nm}$ and $50 \mathrm{~nm}$, respectively.

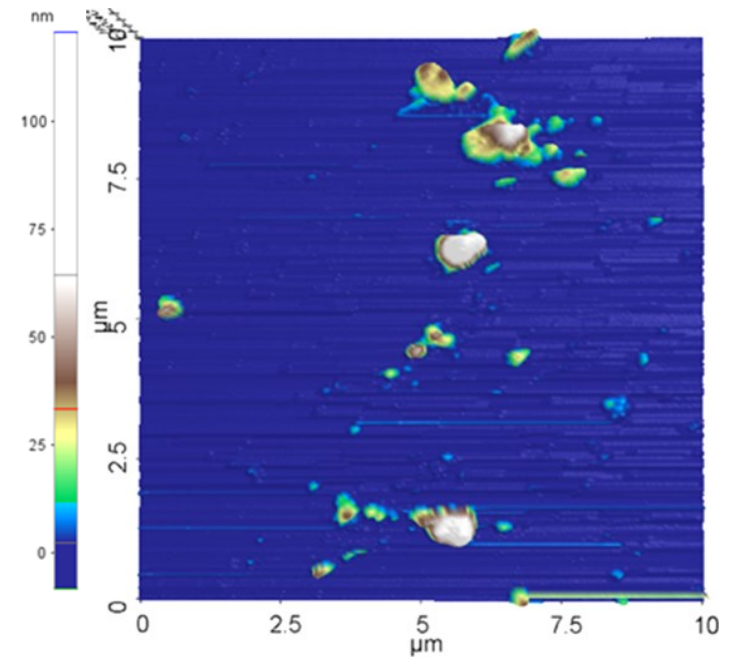

Figure 11 AFM image of dispersed particles taken from $\mathrm{Pb}-\mathrm{Zn}$ flotation tailings 

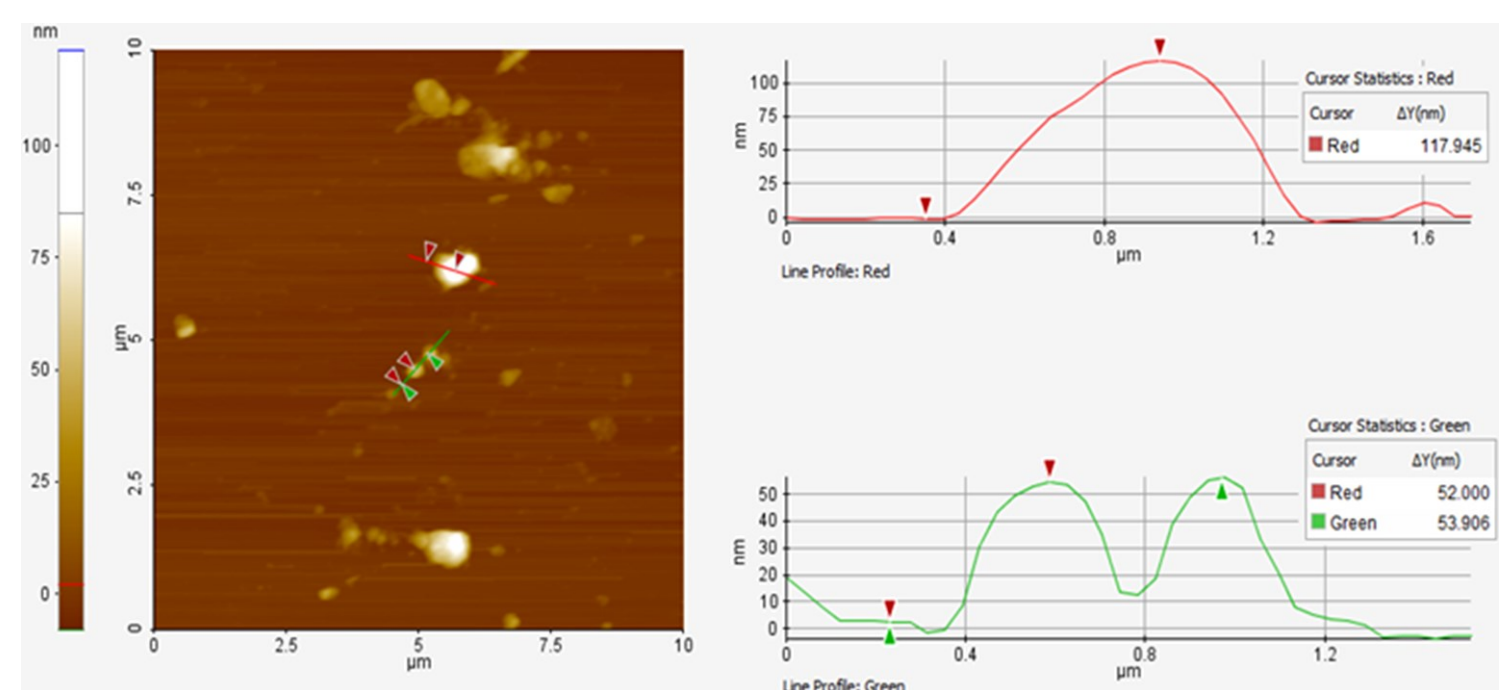

Figure 12 AFM image and cross-sections for $50 \mathrm{~nm}$ (green) and $100 \mathrm{~nm}$ (red) nanoparticles (nominal) deposited on a fresh mica substrate; the differences between the peak height and the average baseline correspond to the particle height of dispersed tailings particles after 5 min stirring in water

During the sulfuric acid leaching step, elemental sulfur started to form and produce a layer around the particles proven by XRD and SEM analysis before [31, 34]. Similar situations in accordance with previous studies were also observed in this study. Figure 13 shows the SEM image of the leach residue particles after 60 min of leaching at $60^{\circ} \mathrm{C}$. The surface of leach residue obtained was probably covered by elemental sulfur, therefore this may be a reason of decreasing dissolution rate after 60 mins of leaching. Similarly, the AFM image of leach residues in Figure 14 suggests that particles varied in size and that there was an increase in the amount of fine particles. Further processing, the leach residue showed a large particle size distribution according to their threedimensional surface profile (Figure 15). Large particles can be identified as partially agglomerated particles (Red line profiles) as $170 \mathrm{~nm}, 22 \mathrm{~nm}$, and $19 \mathrm{~nm}$ of height distributions, whereas majority of the particles was determined to be less than 20 microns. To enhance the leaching efficiency in acidic sulfate solutions, silver, cupric and ferrous ions, and lignosol (sodium lignosulphonate) may be added [31, 34], mechanical activation/turbo-mill grinding may be helpful to crack the sulfur layer [35].

Leached particles with and without pre-roasted were deposited on a mica substrate, and then imaged by thr AFM contact mode (Fig. 16). The roasted tailings prior to leaching and its effect on the sizes of precipitated $\mathrm{Fe}$ particles were investigated from the cross-sectional profiles of the images (Fig. 17).

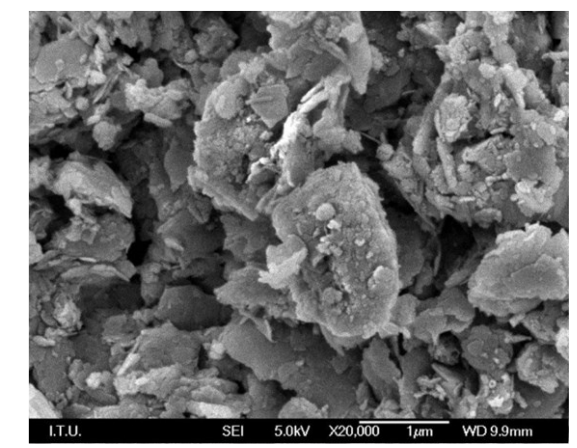

Figure 13 SEM photograph of leach residue

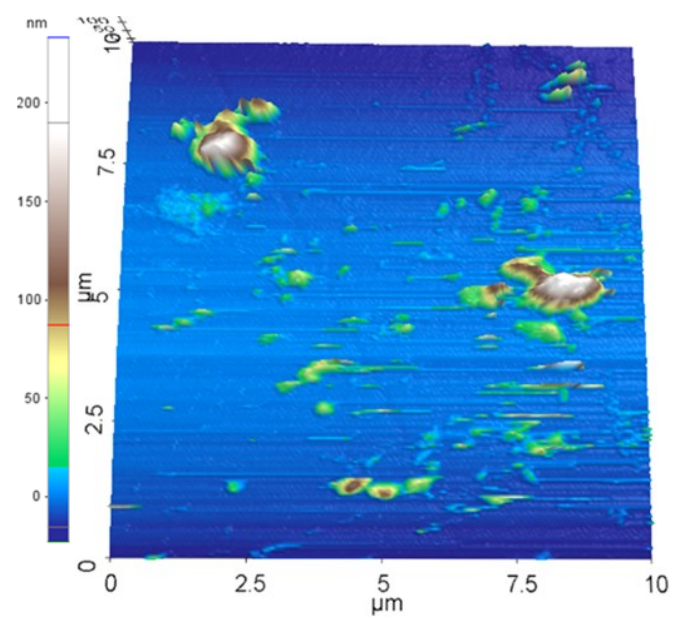

Figure 14 AFM image of dispersed particles from leach residue after 5 min stirring in water 


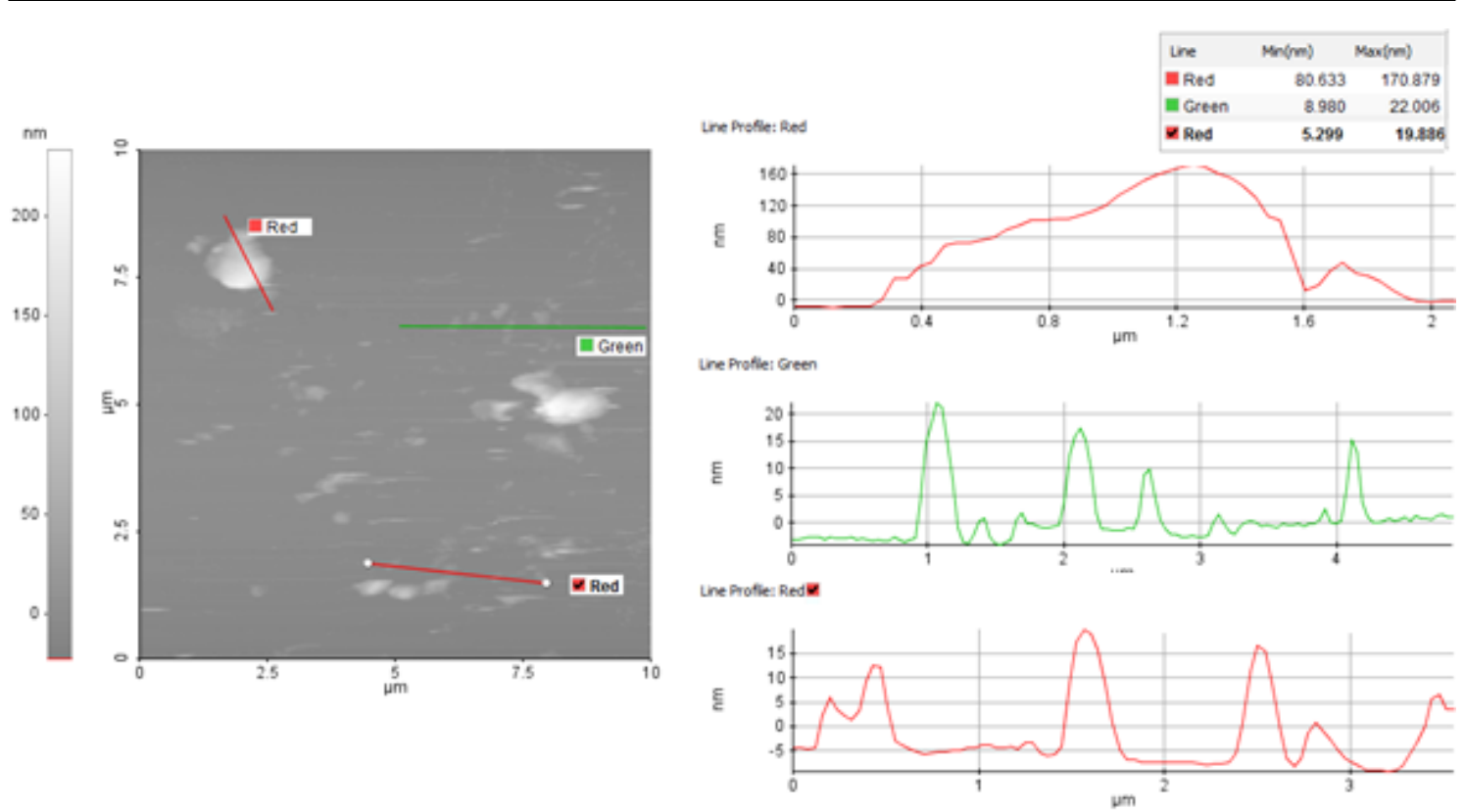

Figure 15 AFM image and cross-sectional height of leached particles for larger particle (red line) and smaller particles below $20 \mathrm{~nm}$ (red and green line) probably represent the elemental sulfur
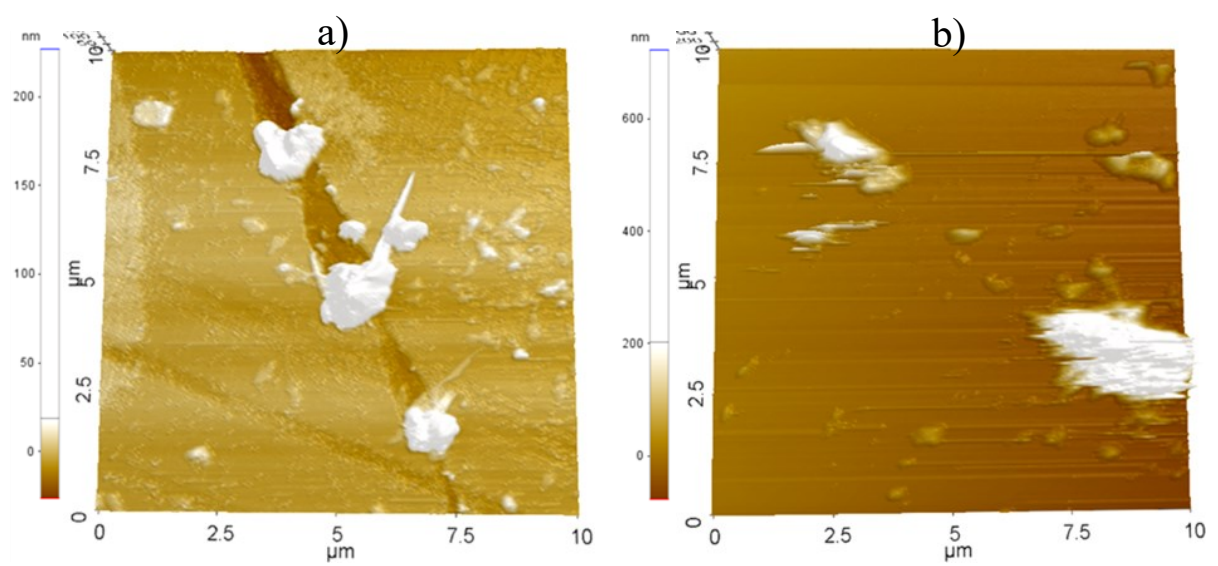

Figure 16 The comparison of precipitated iron (a) roast-leach process, (b) individual leach process

Figure 18 presents $\mathrm{Zn}$-hydroxide precipitate that was in the form of rods as seen from the SEM image. $Z n$ hydroxide precipitate was then subjected to heat treatment in order to produce $\mathrm{ZnO}$. According to XRD diffractions, $\mathrm{ZnO}$ phase in a good agreement with synthetic zincite was in spherical form as seen from the SEM and AFM in Figures 19 and 20, respectively. Similar SEM images were also found in the study on transformation of zinc hydroxide sulphate to crystalline zinc oxide [36].

Figure 21 also shows the line sectional height profiles of $\mathrm{ZnO}$ powders. Synthesized sub-micron $\mathrm{ZnO}$ particles could control the morphology, i.e., rings, bowls, hemispheres, and disks, depending on the reaction temperature, $\mathrm{pH}$, and concentration of additive such as ammonium hydroxide. Moreover, it is known as agglomerated $\mathrm{ZnO}$ nanoparticles with a zincite structure having lack of defined shape and size $[4,37,38,39]$. In the study on production of $\mathrm{ZnO}$ from zinc hydroxide carbonate by Moezzi et al (2014) [40], SEM images of the zinc hydroxide carbonate and the highly porous $\mathrm{ZnO}$ produced also showed that $\mathrm{ZnO}$ product was pseudomorphous with the hydrozincite precursor, as previously reported [41, 42]. 

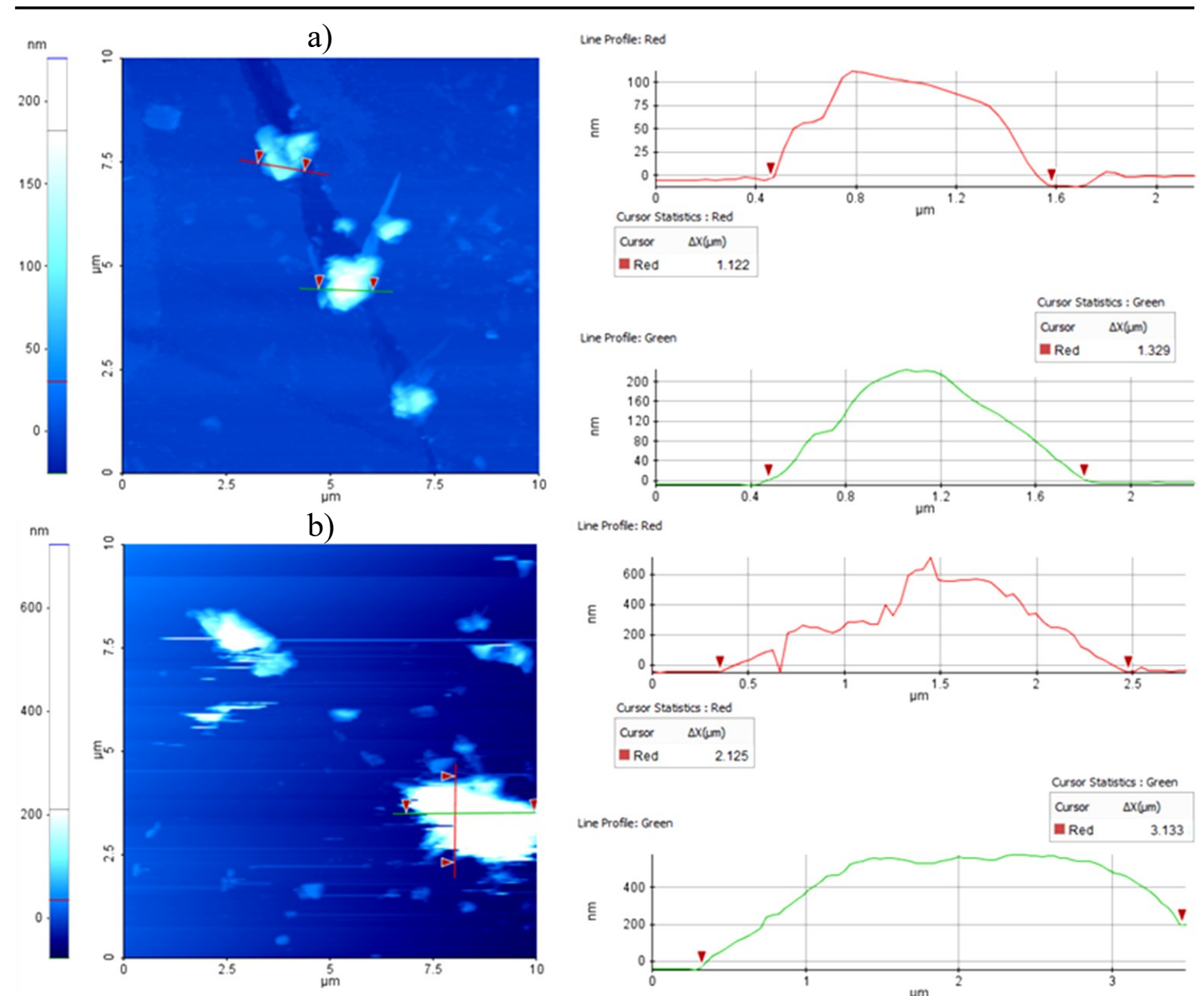

Line Profie: Red

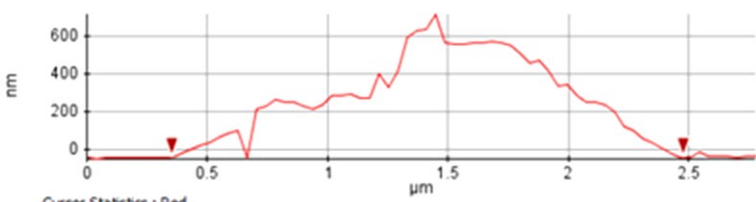

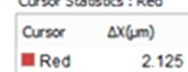

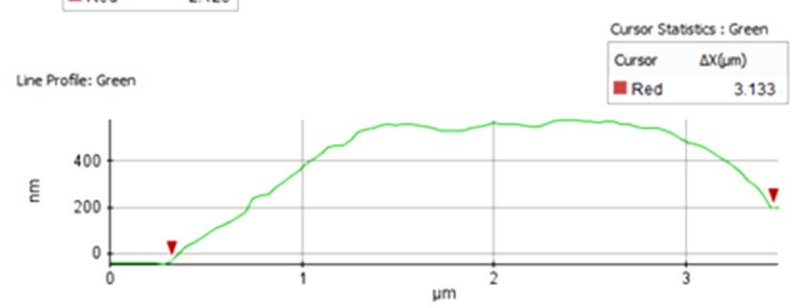

Figure 17 AFM image and cross-sectional height of precipitated Fe particles after (a) roast-leach process, (b) leach process

Figure 20 observed different shapes of the precipitated $\mathrm{ZnO}$ powders on a fresh mica disk as a result of the used preparation route. However, Figure 21 clearly shows the size range of precipitated $\mathrm{ZnO}$ nanoparticles on a mica disk. ZnO nanoparticles were counted under $20 \mathrm{~nm}$ in size and their averaged particle sizes were measured nearly $13 \mathrm{~nm}$ from the AFM image and its image analysis similar to the literature findings [40]. In that study, TEM images revealed that the $\mathrm{ZnO}$ pseudomorphous product is actually a polycrystalline aggregate comprised of individual crystals with sizes in the range of 5 to $20 \mathrm{~nm}$ and amorphous material was also detected [40]. However, in the study on transformation zinc hydroxide sulphate to crystalline zinc oxide, according to SEM studies, highly crystalline ZnO particles are observed, with grain sizes in the range of 100 to 500 $\mathrm{nm}$ [36]. Therefore, it is recommended that the further studies should be conducted on that part.

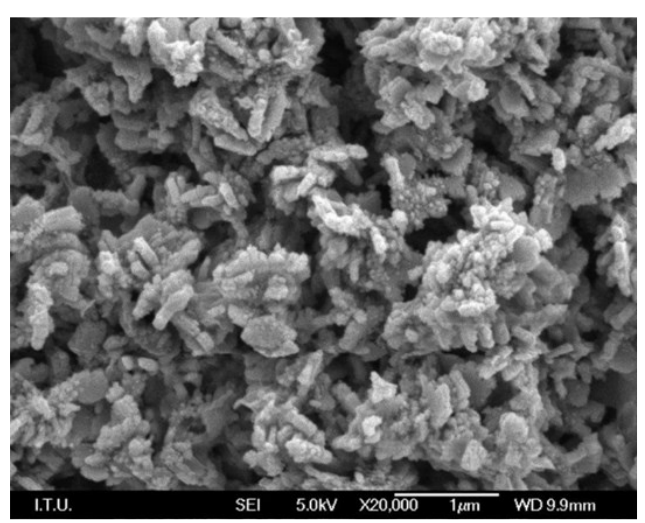

Figure 18 SEM photograph of zinc hydroxide precipitate 


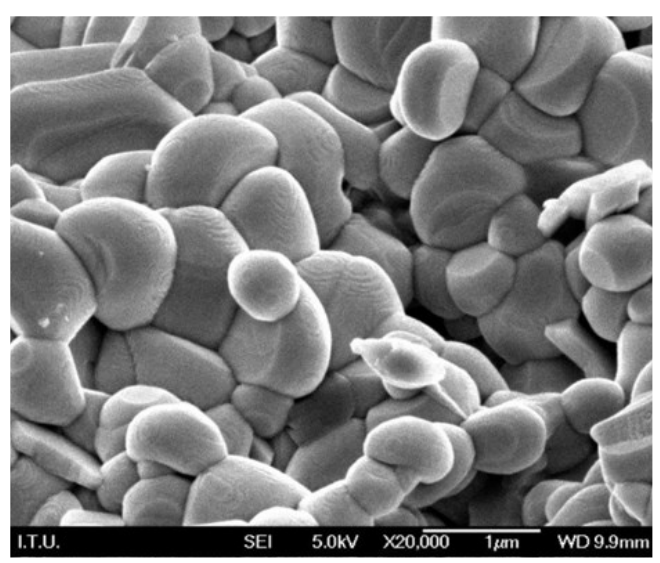

Figure 19 SEM image of $\mathrm{ZnO}$ clusters prepared from the zinc hydroxide

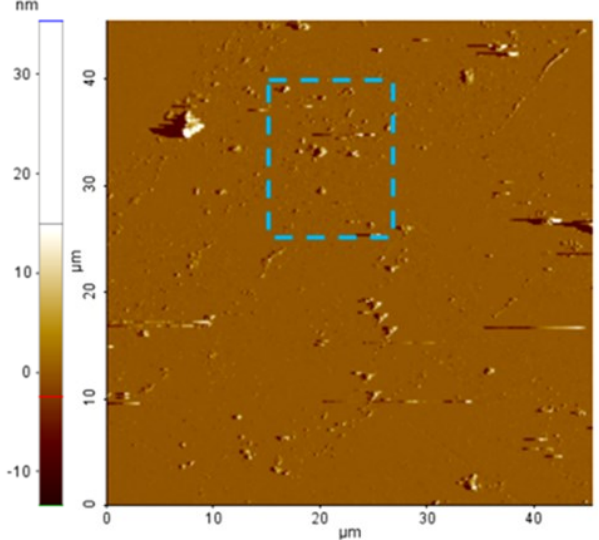

Figure 20 AFM image over $45 \times 45 \mu m^{2}$ regions of the precipitated $\mathrm{ZnO}$ nanopowders on a fresh mica prepared from $\mathrm{Pb}-\mathrm{Zn}$ flotation tailings
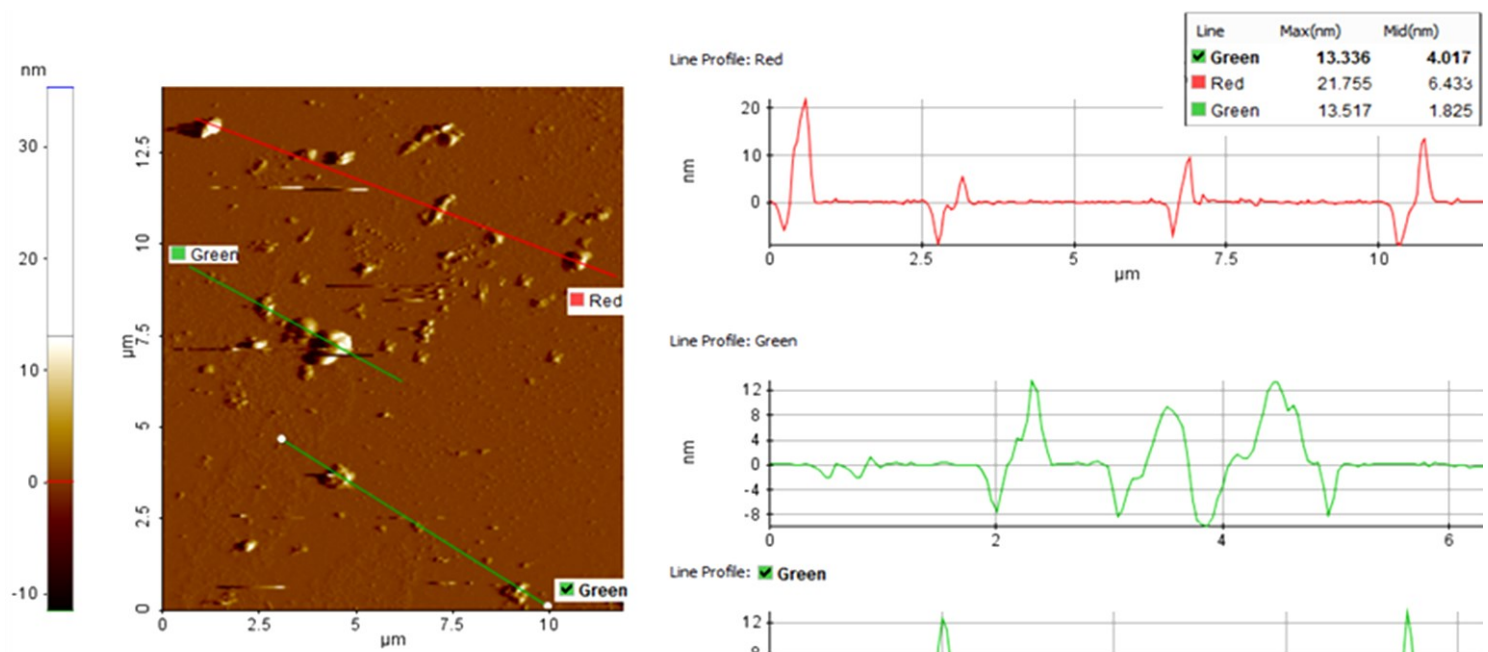

Line Profle: Green

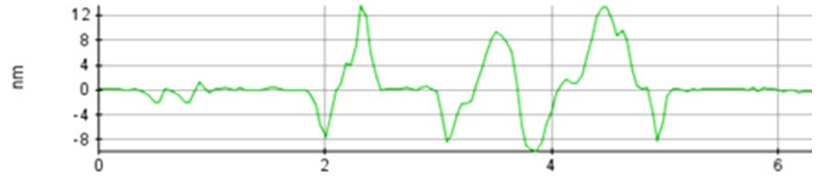

Line Profile: $\mathbf{q}$ Green

$\varepsilon$

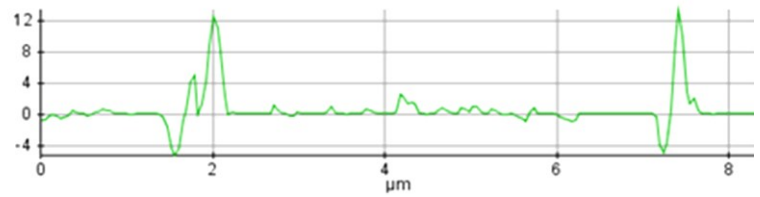

Figure 21 AFM image and cross-sectional heights of $\mathrm{ZnO}$ nanoparticles over $12.5 \times 15 \mu \mathrm{m}^{2}$ regions (blue dashed in

Fig. 18)

\section{Conclusion}

The following conclusions were made as a result of this experimental study carried on lead-zinc flotation tailing:

1) Zinc oxide from the flotation tailings of mixed oxidesulfide lead-zinc ore was successfully recovered by direct hydrometallurgical route and heat treatment when $\mathrm{Zn}$ dissolution efficiency was considered. $83.1 \% \mathrm{Zn}$ and $91.6 \% \mathrm{Cd}$ leaching efficiencies were obtained at the optimum conditions ( $20 \mathrm{~g} / \mathrm{L}$ acid concentration, 1/5 S/L ratio, 1 hour leaching time, and $400 \mathrm{rpm}$ stirring speed) while lead and iron were not dissolved in $\mathrm{H}_{2} \mathrm{SO}_{4}$ and the acid consumption was about $442.9 \mathrm{~kg} / \mathrm{t}$ tailings.

2) Atomic force microscopy (AFM) image of the $\mathrm{Pb}$ $\mathrm{Zn}$ flotation tailings before leaching clearly showed that the particles were in the sizes range of $50-110 \mathrm{~nm}$. During the leaching in sulphuric acid solutions, majority of the particles was determined to be less than 20 microns according to the AFM image analysis. 
3) Elemental sulfur started to form during direct acid leaching and produced a layer around the particles which was also revealed with SEM and AFM images. Leached particles were also identified a partially agglomerated particle in size of $170 \mathrm{~nm}$.

4) Selective precipitations of iron and zinc in the form of hydroxide were performed with high recovery efficiencies of $90.1 \%$ and $99 \%$, respectively. $\mathrm{Zn}$ hydroxide precipitate was in the form of rods according to the SEM photo. After the heat treatment, synthetic zincite structures were produced in the mineral form of $\mathrm{ZnO}$ revealed by its $\mathrm{XRD}$ pattern with no impurity of $\mathrm{Zn}$ and $\mathrm{Zn}(\mathrm{OH})_{2}$. The purity of spherical $\mathrm{ZnO}$ was found at $96.6 \%$.

5) Nanocrystalline $\mathrm{ZnO}$ nanoparticles were also imaged from the AFM image and the nanoparticle image heights were measured less than $20 \mathrm{~nm} \mathrm{ZnO}$ nanoparticles with a mean lateral diameter nearly $13 \mathrm{~nm}$. Therefore, the flotation tailings ore can be a good recycling candidate for the production of high technology needs for nanocrystalline $\mathrm{ZnO}$ nanoparticles.

\section{References}

[1] Singh, S.C., Singh, D.P., Singh, J., Dubey, P.K., Tiwari, R.S., Srivastava, O.N. (2010) Metal Oxide Nanostructures; Synthesis, Characterizations and Applications. In: Umar, A. (Ed.) Encyclopedia of Semiconductor Nanotechnology, American Scientific Publishers.

[2] Ristic, M., Music, S., Ivanda, M., Popovic, S. (2005) Sol-gel synthesis and characterization of nanocrystalline $\mathrm{ZnO}$ powders. J. Alloys Compd., 397, L1-L4.

[3] Brayner, R., Dahoumane, S.A, Claude Yéprémian, C., Djediat, C., Meyer, M., Alain Couté, A., Fiévet, F. (2010) ZnO nanoparticles: synthesis, characterization, and ecotoxicological studies. Langmuir, 26, 6522- 6528.

[4] Vaseem, M., Umar, A., Hahn, Y.B. (2010) ZnO Nanoparticles: Growth, Properties, and Applications. In: Umar, A., Hahn, Y.B. (Eds.), Metal Oxide Nanostructures and Their Applications. American Scientific Publishers, Chapter 4, Volume 5, pp. 1-36.

[5] Hyk, W., Kitka, K., Rudnicki, D. (2019) Selective Recovery of Zinc from Metallurgical Waste Materials from Processing Zinc and Lead Ores. Molecules, 24, 2275, pp: $1-10$.

[6] Zainuddin, N.A., Raja Mamat, T.A., Imam Maarof, H., Puasa, S.W., Mohd Yatim, S.R. (2019) Removal of Nickel, Zinc and Copper from Plating Process Industrial Raw Effluent Via Hydroxide Precipitation Versus Sulphide Precipitation, Joint Conference on Green Engineering Technology \& Applied Computing 2019, IOP Conf. Series: Materials Science and Engineering 551 (2019) 012122, IOP Publishing.

[7] Caproni, G., Ciccu, R., Ghiani, M., Trudu, I. (1979) The Processing of Oxidized Lead and Zinc Ores in The Campo Pisano and San Giovanni Plants (Sardinia), XIII International Mineral Processing Congress, Processing of Oxidized and Mixed OxideSulphide Lead-Zinc Ores, Warszawa, pp.71-91.

[8] Hosseini, S.H., Forssberg, K.S.E. (2002) Flotation of Oxidized Lead \& Zinc Minerals from Angooran Deposit in Zanjan Province, Iran. IX International Mineral Processing Symposium, Extended Abstracts, 18-20 September, Cappadocia, Turkey, pp.105-106.

[9] Önal, G., Abramov, A.A. (2002) Optimal Conditions for Oxide Lead Minerals Flotation, IX International Mineral Processing Symposium, Extended Abstracts, 18-20 September 2002, Cappadocia, Turkey, 107-108.

[10] Onal, G., Bulut, G., Gül, A., Kangal, O., Perek, P.T., Arslan, F. (2005) Flotation of Aladag oxide lead-zinc ores. Miner. Eng. 18, 279-282.

[11] Perek, T., Benli, B., Arslan, F. (2011) Recovery of zinc from lead-zinc flotation tailings by leaching and precipitation. XIV International Balkan Mineral Processing Congress, June 14-16, Tuzla, Bosnia and Herzegovina.

[12] Buban, K.R., Collins, M.J., Masters, I.M. (1999) Iron control in zinc pressure leach processes, JOM, 51, 23-25.

[13] Principe, F.T., Demopoulos, G.P. (1999) The separation and concentration of iron from zinc process solutions. JOM, 51, 34-35.

[14] Ismael, M.R.C., Carvalho, J.M.R. (2003) Iron recovery from sulphate leach liquors in zinc hydrometallurgy. Minerals Engineering. 16, 31-39.

[15] Orhan, G. (2005) Leaching and Cementation of Heavy Metals from Electric Arc Furnace Dusts, Hydrometallurgy. 78, 236-245.

[16] Jitianu, M., Goia, D.V. (2007) Zinc oxide colloids with controlled size, shape, and structure. Journal of Colloid and Interface Science. 309, 78-85.

[17] Arslan, F., Aykaç, Y., Perek, K.T., Bakan, S., Önal, G. (2004) Leaching of Lead-Zinc Flotation Tailings, Proceedings of Xth International Mineral Processing 
Symposium (Challenges and Opportunities in Mineral Processing), Çeşme-Turkey, pp. 667-671.

[18] Arslan, F., Aykaç, Y., Perek, K.T., Bakan, S., Önal, G. (2006) Evaluation of Lead-Zinc Flotation Tailings, in: Kongoli, F., Reddy, R.G. (Eds.), Sohn International Symposium on Advanced Processing of Metals and Materials: Thermo and physicochemical principles: special materials, aqueous and electrochemical processing, Volume 3 , San Diego, USA, pp.387-395.

[19] Rahman, M.M., Qadir, M.R., Neger, A.T., Kurny, A.S.W. (2013) Studies on the Preparation of Zinc Oxide from Galvanizing Plant Waste. American Journal of Materials Engineering and Technology. 1, 4, 59-64.

[20] Ruiz, O., Clemente, C., Alonso, M., Alguacil, F.J. (2007) Recycling of an electric arc furnace flue dust to obtain high grade ZnO. J Hazard Mater., 141 (1), 33-6.

[21] Tsakiridis, P.E., Oustadakis, P., Katsiapi, A., Agatzini-Leonardou, A. (2010) Hydrometallurgical process for zinc recovery from electric arc furnace dust (EAFD). Part II: Downstream processing and zinc recovery by electrowinning. Journal of Hazardous Materials, 179, 8-14.

[22] Kunicky, Z., Jandova, J., Dostal, J., Dvorak, P. (2008) Zinc Recovery From Wastes Using Spent Acid From Scrapped Lead Acid Batteries. International Symposium on Lead and Zinc Processing, The Southern African Institute of Mining and Metallurgy, Republic of South Africa, pp. 247 254.

[23] Solookinejad Gh., Rozatian A.S.H., Habibi M.H. (2016) Zinc Oxide Thin Films Characterization, AFM, $\mathrm{XRD}$ and X-ray Reflectivity, Experimental Techniques (2016) 40: 1297-1306, Society for Experimental Mechanics.

[24] Benli, B. (2014) Effects of humic acid release from sepiolite on the interfacial and rheological properties of alkaline dispersions, Applied Clay Science, 102, 12/2014, 1-7.

[25] Plaschke, M., Schafer, T., Bundschuh., T., Manh, T.N., Knopp, R., Geckeis, H., Kim, J.I. (2001) Size characterization of bentonite colloids by different methods. Anal. Chem., 73, 4338-4347.

[26] Bickmore, B.R., Hochella, M.F., Bosbach, D., Charlet, L. (1999) Methods for performing atomic force microscopy imaging of clay minerals in aqueous solutions. Clays Clay Miner., 47, 573-581.
[27] Doutt D.R., Brillson L.J. (2011) Nanoscale AFM and KPFM Mapping of Localized Charge and Recombination Centers on Chemically active $\mathrm{ZnO}$ Surfaces, Case Study: ZnO Surfaces, Park System Applications Note, 1-5.

[28] Maroufa, S., Beniaichea, A., Guessasa, H., Azizib, A. (2017) Morphological, Structural and Optical Properties of ZnO Thin Films Deposited by Dip Coating Method, Materials Research, 20(1): 88-95.

[29] Katı, N. (2019) Investigation of Optical and Morphological Properties of Co Doped ZnO Nanomaterials, Turkish Journal of Science \& Technology, 14(1), 41-48.

[30] Pourbaix, M. (1974) Atlas of Electrochemical Equilibria in Aqueous Solutions, Second English Edition, NACE (National Association of Corrosion Engineers) Houston, Texas, International Cebelcor.

[31] Perek, K.T., Arslan, F. (2003) Recovery of Metallic Values from Küre Massive Rich Copper Ores by Pressure Leaching, Istanbul Technical University Journal/d-Engineering, 2 (3), 65-72.

[32] Yoshida, T. (2003) Leaching of Zinc Oxide in Acidic Solution, Materials Transactions, Vol. 44, No. 12, pp. 2489-2493.

[33] Kim, Y., Lee, J. (2016) Leaching Kinetics of Zinc from Metal Oxide Varistors (MOVs) with Sulfuric Acid, Metals, 6, 192.

[34] Arslan, F., Bulut, G., Kangal, M.O., Perek, K.T., Gül, A., Gürmen, S. (2004) Studies on Leaching of Massive Rich Copper Ore Acidic Ferric Sulfate Solution, Scandinavian Journal of Metallurgy, 33 (1), 6-14.

[35] Cobble, J.R., Jordan, C.E., Rice, D.A. (2003) US Bureau of Mines RI 9472.

[36] Moezzi, A., Cortie, M.B., McDonagh, A.M. (2013) Zinc hydroxide sulphate and its transformation to crystalline zinc oxide, Dalton transactions, Issue 42, $14432-14437$.

[37] Lee, B.W., Koo, J.H., Lee, T.S., Kim, Y.H., Hwang, J.S. (2013) Synthesis of ZnO Nanoparticles via Simple Wet-Chemical Routes, Advanced Materials Research, Vol. 699, pp 133-137.

[38] John, M., Heuss-Aßbichler, S., Ullrich, A. (2016) Recovery of $\mathrm{Zn}$ from wastewater of zinc plating industry by precipitation of doped $\mathrm{ZnO}$ nanoparticles, Int. J. Environ. Sci. Technol. (2016) 13:2127-2134.

[39] Shamhari, N.M., Wee, B.S., Chin, S.F., Kok, K.Y. (2018) Synthesis and Characterization of Zinc Oxide 
Nanoparticles with Small Particle Size Distribution, Acta Chim. Slov. 65, 578-585.

[40] Moezzi, A., Cortie, M., Dowd, A., McDonagh, A. (2014) On the Formation of Nanocrystalline Active Zinc Oxide from Zinc Hydroxide Carbonate, Journal of Nanoparticle Research, 16, Article Number: 2344.

[41] Castellano, M., Matijevic, E. (1989) Uniform colloidal zinc compounds of various morphologies, Chemistry of Materials, 1:78-82.
[42] Kanari, N., Mishra, D., Gaballah, I., Dupré, B. (2004) Thermal decomposition of zinc carbonate hydroxide, Thermochimica Acta 410:93-100.

[43] Jandová, J., Dvorák, P., Jiričný, V., Mráz, R. (2003) Recycling of ZnO Flue Dust to Produce Zinc by Hydrometallurgical Routes, in: Young, C., Alfantazi, A., Anderson, C., James, A., Dreisinger, D., Harris, B. (Eds.), Electrometallurgy and Environmental Hydrometallurgy, John Wiley \& Sons, Inc., Hoboken, NJ, Volume 2, pp.1509-1603.

\title{
DOBIJANJE ZnO IZ FLOTACIJSKE JALOVINE KOJA SADRŽI OLOVO I CINK HIDROMETALURŠKIM POSTUPCIMA - XRD, SEM I AFM ANALIZE
}

\author{
K.T. Perek', B. Benli' , C. Arslan², F. Arslan" ${ }^{1 \#}$ \\ ${ }^{1}$ Istanbul Technical University, Mineral Processing Engineering Department, Istanbul, Turkey \\ ${ }^{2}$ Istanbul Technical University, Metallurgical and Material Engineering Department, Istanbul, Turkey
}

(Primljen: 14. januar 2020.; Prihvaćen: 23. mart 2020.)

\begin{abstract}
Izvod
Hidrometalurška metoda za dobijanje cink hidroksida i sintezu ZnO nanokristalne strukture predstavlja veoma interesantnu metodu za dobijanje oksida olova i cinka iz flotacijske jalovine koja sadrži olovo i cink. U Turskoj, rude koje pored olova i cinka imaju i visoki sadržaj gvožđa nisu pogodne za uobičajene metode koje se koriste za preradu mineralnih sirovina i potrebno je koristiti hidrometalurške metode. Stoga, kontrola gvožđa tokom postupaka koji uključuju cink je veoma važna. U ovom radu je ispitivana hidrometalurška metoda za dobijanje cinka iz $\mathrm{Pb}-\mathrm{Zn}$ flotacijske jalovine tako što je ispitivan uticaj koncentracije $\mathrm{H}_{2} \mathrm{SO}_{4}$ i temperature prilikom luženja i prženja na rastvaranje cinka uzimajući u obzir promenu redoks-potencijala i pH vrednosti. Dobijeni uzorci gvožđa i cinka su pojedinačno analizirani metodama rentgenske difrakcije (XRD), pretražnog elektronskog mikroskopa (SEM) i mikroskopa atomskih sila (MAS) (engl. Atomic Force Microscope, AFM) da bi se uporedili uzorci pre i posle luženja, taloženja i prženja. Dobijeno je 83,1\% Zn i 91,6\% Cd postupkom luženja iz Pb-Zn flotacijske jalovine, gde su veličine čestica bile od 50 do 110 nm što se vidi na presecima slika dobijenih mikroskopijom atomskih sila, dok se olovo i gvožđe nisu rastvorili. Elementarni sumpor je počeo da se formira i stvara sloj oko čestica ili delimično nagomilanih čestica veličine $170 \mathrm{~nm}$ tokom postupka luženja u prisustvu sumporne kiseline. Međutim, utvrđeno je da je veličina većine čestica bila manja od 20 mikrona, a slike dobijene mikroskopom atomskih sila su pokazale da se veličina luženih i neluženih čestica razlikovala za više od $50 \%$.

Selektivno taloženje gvožđa i cink hidroksida je postignuto u velikom procentu, $90,1 \%$ gvožđa i $99 \%$ cinka. Nakon termičkog postupka, dobijeni su klasteri cinka čistoće 96,6\% u obliku minerala ZnO i veličine skoro $13 \mathrm{~nm}$. Dobijanje cinka se može smatrati uspešnim, a flotacijska jalovina se može posmatrati kao dobar kandidat za proizvodnju visokotehnoloških nanočestica ZnO sa nanokristalnom strukturom.
\end{abstract}

Ključne reči: Pb-Zn rude; Luženje; Taloženje; Klasteri cink oksida; Struktura cink-oksida. 